\title{
Features and Prospects of Development of The Labor Market in Uzbekistan
}

\author{
Salimov Sherzod* \\ Department of Scientific Research, Uzbekistan

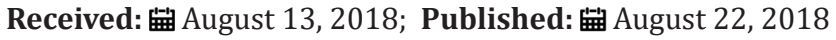 \\ *Corresponding author: Salimov Sherzod, Scientific researcher, Tashkent, Uzbekistan
}

\begin{abstract}
There are different approaches on determining the object that causes of buying-selling interactions in labor market. Discussions about labor market has been continuing since the middle of the last century. If the economists of CIS countries had the common view about it before the market economy, it becomes intricate under the influence of western economics. From practical point of view, among the whole population of Uzbekistan the tendency of the growth of the population of working age and the shrink of dependency is observed, which requires to increase the number of employed among economic active population. It is important to mention that, during the financial-economic recession, the republic of Uzbekistan adopted anticrisis program, which mainly directed to the most important problems such as creating new labor places and improving the living standards of the population.
\end{abstract}

Keywords: Labor market; Labor resources; Employment; Demographic trends; Labor immigration

\section{Introduction}

Formation of the labor market and its infrastructure, creating new labor relations confronts theory and practice task thorough and objective investigation of these processes. In addition, the deepening of market relations increases the urgency of issues related to balance demand and supply of labor, wages (price of labor), unemployment, training and retraining of skilled labor, the creation of a competitive environment in the labor market, the development of human resources. Acuteness of the problems of employment and labor market development work required for profound monographic studies of complex scientific papers, develop evidence-based recommendations and proposals to address them. Accordingly, the economics of Uzbekistan was initiated to develop a scientific theory and a methodological basis for the formation of employment and labor market development in the new environment based on global experience in the formation, operation and regulation of the labor market. Development of effective policy formation of the labor market in the country is impossible without considering the specific features that are unique to Uzbekistan. The experience of developed countries shows that the change in one or other structure is influenced by national characteristics, socio-economic conditions prevailing at a particular stage of development of each country. In this regard, the development of a theory and methodological foundations of market development work focuses on the study of the specific features of the country, causing the creation of a national model.

Theoretically profound study of the labor market as a multifaceted socio-economic phenomenon begins with a study of its essence. Labor market as an economic category has always been the subject of study as representatives of classical economics and modern academic economists. In addition, their approaches to the definition of the labor market, its analysis, the views on the mechanism of functioning and regulation differed radically [1-15]. In all approaches, there is recognition that the labor market is a system of social-economic relations between buyers and sellers about sales peculiar commodity - labor force, more precisely, the ability to work. While among the sellers and buyers, competition takes place: among the first - for the right to engage in decent jobs, among the second - for skilled workers [14]. The labor market has a significant role not only in the times of financial and economic crisis, but also in all stages of the economic cycle and it is an actual problem at all stages of economic development. The labor market is a key element of production, industry and is directly related to human resources and their life. To solve the problems of the labor market requires a deep knowledge of labor law and specific goals 
to achieve certain results. If you look at the labor market from a scientific point of view, the main influence on the labor market has a demographic characteristic. Since Independence of the Republic of Uzbekistan (1991-2013) population increased by 66.2 percent or 9.7 million people, and the workforce increased by 62.7 percent. If in 1991 the labor force was 49.2 per cent, by 2013 it had risen to 61.7 percent [16].

According to the observation of the Cabinet of Ministries of the Republic of Uzbekistan in 2013 the population of the country was 30,5 million people, of whom 51.1 percent lived in urban areas and 48.9 in rural areas. In addition, population growth in 2013 grew to 60,8 percent than in 2008 and rural population dropped to 16,3 percent. In this period, urban population grew for 35,3 to 51,1 percent and rural population dropped from 64,7 percent to 48,9 percent. It clear that urban population is growing and it because of governmental act "About development of administrative and territorial places of population", which was adopted in 13th of March 2009.

Summary demographic development of the country is shown in the fertility decline. This affects the level indicator of youth. In 1991, the composition of the young population under age of 16 fell from 42.9 percent to 30.2 percent. The average age of youth is 25.5 years, including in rural areas 24.1 years, in urban areas 27.9 years. According to world demographic indicators, Uzbekistan can be added to the list of countries with population of which the majority is younger generation. As it can be seen, the major part of the population of able-bodied people and compelling cost in coming years will join the labor force two fifths of the population, which is currently up to 16 years and it will keep a sharp labor market situation.

Demographic weight on 1,000 people, from 1035 to 1991 , decreased by 652 people in 2010, and in 2013 decreased to 620 people. It should be emphasized that the demographic load acts only when the population fully secured with work. If the demographic load includes the number of unemployed, the figures may increase. Intensive generation rate changed in 2000 was 5.6, 5.3 in 2005, 4.2 in 2010, 2,9 in 2013. There is an equality between people who new to labor market and people, who leaves labor market. In 2025, under employment age people will drop to 5, 8 percent, workforce will rise to 2, 2 percent and over workforce age people will also rise to 3, 8 percent. In 2013 the number of people busy with work amounted to 12.2 million. In 1991 this number was 7.9 million, in 2000 was 9 million, and in 2005 was 10.2 million, and in 2010 was 11.6 million or 54.7 percent more than in 1991 [17].

During the Independence years, development of labor resources increased by 62.7 percent and significantly increased the level of employment. In 2006-2010, the level of employment and the level of labor force reached the same level. This is due to the strong policy of our country in the field of employment. If you show the level of development dynamics in economic sectors, over the past 7 years, employment rate rose by 2.7 percent. 1.7 percent of them work in the real sector, 4.1 percent of the population work in the field of transport, communications and construction. 5.4 percent of the employed population working in municipal and general nutrition and 2.8 percent work in the social sphere [17]. Modernization and economic development, as well as paying special attention to the development of technology are positive impact in the development of the real sector practice. Practice proves us in the example of developed countries that for the development of employment in the service sector, we need to develop infrastructure and enterprises within the real sector. In the real sector, the share of employed people across the country composes 40.7 percent. It is 2 times more than in the social sector, and 3 times more than in the transport and construction sectors.

In the process of social-economic reforms focuses on the development of the national economy and the transformation of the private sector in market economy. Mixed economy, the development of property and freedom of the economy has a positive effect on the development of enterprise and private ownership. If we analyze the employed population by sex, in 2012, 5.6 million of the employed population (45.4 per cent) composed women. During the 19912012 years, the employment rate of women has increased by 1.87 million people, or 50.8 percent. During these years, the employment rate of men increased by 2.0 million people, or 44.3 percent. Increasing employment of able-bodied women is associated with the development of sector structures and infrastructures, as well as the development of industry, which require the work of women. If we analyze the employment rate of women in agriculture sector, it is noted that this level is relatively decreased. In 2012, 28.3 percent of employed women in the territory of the Republic of Uzbekistan worked in agriculture. If we compare this figure with other statistics, it becomes clear that 35.4 percent of employed women around the world are working in agriculture, in South Asia 64.5 per cent and 2.9 per cent in developed countries. In our Republic Public health, education and cultural activities become major traditional areas of work for women.

In 2012, 32.9 percent of working women are actively working in this field. 79.4 percent of employed women worked in the field of Health and Welfare, 72.4 percent of women in education sector. Economic activity of women in the Republic of Uzbekistan at high level and in 2012 the figure was 68.9 percent and it is 15.8 percent more than the average worldwide. If you give an example of growth in GDP and population growth, in 1990, the GDP growth rate was lower than the population growth, but in 1997, GDP grew by 3.3 percent, in 2010 by 6.8 percent and in 2013 by 6.5 percent. After analyzing the mechanism of the labor market, it becomes clear that there is no logical reason to include the economically active population in the labor force, which enters into the labor market to find a job. In this case, the labor force as a commodity comes 
in first place, and production work becomes secondary. If people got a job for their possible potential, their potential power would pass to the second level. As a result, after the implementation of labor, part of employed people is included to the list of people who are looking for a job. One of the directions of labor market is labor migration. Labor immigration has a positive and a negative role in the labor market. Positive aspects of immigration are that it reduces the population pressure, helps to reduce unemployment and improves some elements of the economic situation. Negative aspects of immigration are illegal work and the fabric of life in another country.

In addition, people who work as an immigrant in a foreign country do not work as professionals and they lose skills in their specific specialty. Negative consequences of migration also affect the education of their children, social-demographic process and problems in family relationship. Development of healthy competition, a variety of property in economic transition has changed the quality of demand in the labor market. Development of the social and economic structure and development of the quality of service require specialists with higher education and knowledge of modern technology. Changes in the education system, the creation of new jobs and professions, as well as the economic activity of the workers are the basis of changes in the social and economic sphere and rises to a new level. Labor activity of the population, especially of young people associated with the economic, social, and demographic processes, and most important of them is the employment of graduates of colleges and direction of their specialty. The 1997 "National Program for Personnel Training" has played an important role in the creation of professional colleges, training of professional personnel and training in the context of the national labor market. Governmental labor program 2014 aims to increase number of private firms and companies and make new workplaces, to create and reorganize agricultural sector for further development and to develop transportation and services in order of make new work places. Nowadays, the population of Uzbekistan is 30.5 million people and it increased 1.5 times in 1991-2013 years. $70 \%$ of them are labor force and they present powerful source for national economy. $58 \%$ of total population is coming to labor market soon; most of them are graduates from universities and colleges.

According to 2014 program, level of employment will rise 2.2-2.5 times and unemployed will not rise more than 5 percent. Nowadays, demand for jobs is 1291, 1 and 983.6 jobs will be created for them and 630.4 thousand of people need workplaces and 52 thousand of them are returned immigrants. Labor program has seven main directions, where 6 percent of new jobs will be created in industrial companies, 37.6 percent in small business, 11.4 percent in private sectors, 22.5 percent (home-made work), 14 percent in agricultural sector. Then, 6.8 percent jobs will be created by developing infrastructures and 1.5 percent by recovering bankrupted organizations. If in professional colleges there is no big difference in training in the field of economy and the real sector, the universities and the training of social realistic training is 64.8 percent, of which 89.3 percent in education, 18.2 per cent in real sector (73.3 per cent of them in the manufacturing sector). Preparing young people for the work depends largely on the social and economic situation of the country. Career choice and training of personnel for work helps improve the level of production, saves capital, increases the level of responsibility of the citizens and workers show a tendency for the better.

\section{Conclusion}

During the transitional period in the development of the labor market and demographic changes, as well as from the perspective of the scientific point of view, followings are concluded:

a) Strengthening the power of demographics and increasing employment will improve the social economic situation on the ground;

b) The growth of the population on a territorial basis. In all areas fertility is reducing itself, and it positively affects the young segment of the population;

c) According to statistics, the level of employment is gradually increasing, it also grows favorable conditions in the labor market. Growing component of the active working population and this has a positive effect on the social conditions of the population. We must pay attention to youth employment and effective use labor resources in the territory of the Republic. Also requires paying attention to the development of the activities of the economic sphere;

d) If we analyze employment by sphere, it is noticeable that in 2008 during the global crisis on the planet, it was drop in industry, supply and trade, but in 2009 in our country by the national program of the government and by industry, many jobs were created and it had a positive impact on employment, which helped the country during the global crisis to get rid of unemployment, as well as through economic policies many new jobs had been created, because of the crisis, immigration has declined sharply.

e) Analysis of college trainings showed that general training of students should pay particular attention to the areas of development of domestic production and infrastructure, and colleges should train personnel by industry sphere. Modernization and privatization of industries require new training in specific sectors and this has a positive effect on the labor market.

f) There is a difference in training in economic fields between the graduates of colleges and universities. Although the two institutions' social areas have an important role in 
the direction of graduates, medicine concentrated colleges ahead of university students and university graduates are ahead in education sphere. Here, it is necessary to emphasize that the state pays special attention to development of health infrastructure on the ground. It is also due to the development of medicine and nursing services, as well as the demand for health care workers.

g) The same situation is observed in the field of agriculture and industry. Graduates of colleges are leaders in the field of agriculture and university graduates are in demand of the industry. Since developing of industry, agriculture and technology, as well as a growing need for professional staff, many businesses need reliable personnel for the development of the industry. Training also helps the development of small enterprises and agriculture.

\section{Recommendations}

a. Promote the labor market and demographic analyzes, as well as keep in mind the national interests of regional development;

b. Regional programs to promote employment and to promote the general programs for the development of local labor market;

c. Broaden the range and quantity of labor fairs and general information channels, job seekers could find reliable information on the work;

d. Effectively use the services of the trade unions and in practice of developed countries to develop four parties of the contract to ensure graduates of colleges, as well as training on specific aspects of the industry;

e. Development training in colleges and universities for economic infrastructures in the whole country, where business in the process of modernization and development technologies need new frames. Determine the level of demand in the labor market and train personnel for popular industry destinations;

f. For the purpose of legal assistance to graduates of colleges and universities, who are applying for a job for the first time, help them with employment and promotion in the Legislation of changes that have been made by the Parliament of the Republic of Uzbekistan. It is vital to develop legal relations on the labor market and develop activity of non-governmental organizations to improve communication between government agencies and enterprises, as social cooperation.

\section{References}

1. Marshall A (1993) Principi ekonomicheskoy nauki. Moscow: Progress.

2. Schumpeter I (1982) Teoriya ekonomicheskogo razvitiya. Moscow: Progress.

3. Ehrenberg R, Smith R (1996) Sovremennaya trudovaya ekonomika. Teoriya i gosudarstvenaya politika. Moscow: Moscow State University.

4. Rofe A, Zbyshko B, Ishin V (1997) Rynok truda: ekonomika trudovykh resursov. Moscow: Progress.

5. Kornejchuk B (1998) Diskriminatciya rabotnikov tvorcheskogo truda (ekonomicheskiy aspekt). St.Petersburg, Russia: Saints Petersburg State University.

6. Rofe A (1997) O podderjanii ponyatiya "trudovye sily" i "rabochie sily". Chelovek i trud 3: 25.

7. Kotlyan A (1996) Problemy zanyatosti ostayutsya aktualnymi. Chelovek i trud 5: 10 .

8. Plaksja V (1996) Bezrabotitsa v rynochnoy ekonomike. Moscow: Russian Academy of Humanitarian Science.

9. Bulanov V (1997) Nekotorye metodicheskie voprosy izucheniya rynka truda. Obshestvo i ekonomika 8: 67-68.

10. Kovrizhnyj A (1995) Dvijenie rabochey sily v usloviyah rynka truda i voprosy upravleniya. Barnaul: Altay State Technical University.

11. Maksakova L (1995) Problemi obespecheniya zanyatosti trudovih resursov Respubliki Uzbekistan v perehodnom periode. Tashkent: FAN.

12. Abdurahmonov Q (2004) Socialnaya zashita naseleniya. Tashkent: Tashkent State Economical University.

13. Ismailova L (1993) Faktory sprosa i predlojeniya na rynke truda, bezrabotica i formy ego proyavleniya. Moscow: Institute of Economy of the Russian Academy of Science.

14. Hudoyberdiev Z (2008) Rynok truda na perehodnom periode: teoriya i praktika. Tashkent: Finance.

15. Artikova D (2005) Formirovaniye zanyatosti v Respublike Uzbekistan. Tashkent: FAN.

16. Statisticheskie byulleteni. Naselenie Respubliki Uzbekistan na (2001) 2006; 2009; 2013 gody. Tashkent: Committee of statistics of the Republic of Uzbekistan.

17. Statisticheskie byulleteni. Trud i zanyatost v Uzbekistane na (2001) 2006; 2009; 2013 gody. Tashkent:Committee of statistics of the Republic of Uzbekistan.

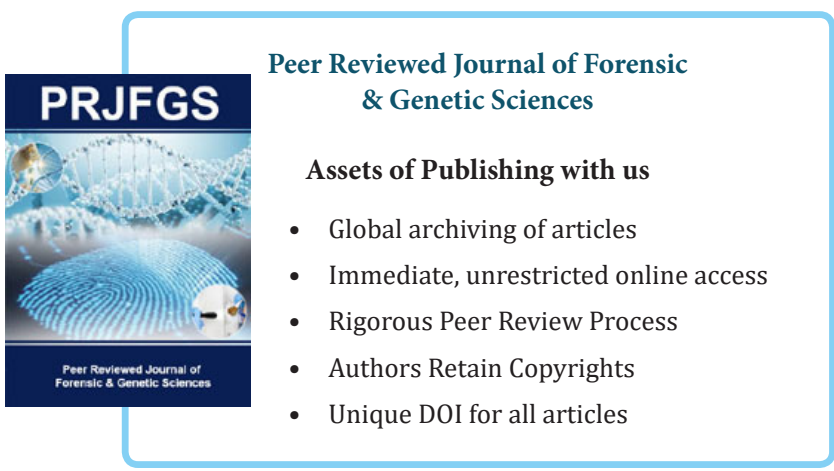

